\title{
Population genetic structure of mussels from the Baltic Sea
}

\author{
H.-P. Bulnheim ${ }^{1}$ \& E. Gosling ${ }^{2}$ \\ ${ }^{1}$ Biologische Anstalt Helgoland (Zentrale); Notkestr. 31, D-2000 Hamburg 52, \\ Federal Republic of Germany \\ ${ }^{2}$ Regional Technical College, Galway, and Zoology Department, University College; \\ Galway, Ireland
}

\begin{abstract}
In a macrogeographic survey, the population genetic structure of mussels from various regions of the Baltic Sea, a large semi-enclosed brackish-water basin, was examined with reference to Mytilus edulis and $M$. galloprovincialis samples from the North Sea, Irish coast and southern Portugal. Electrophoretically detectable variation was analysed at 6 polymorphic enzyme loci (Ap, Est-D, Lap-2, Odh, Pgi and Pgm). Evidence was provided of a remarkably large amount of biochemical genetic differentiation among ecologically and morphologically divergent mussel populations in the Baltic. Patterns of allele frequencies in low-salinity populations from the area of the Baltic Proper were demonstrated to be widely homogeneous but contrast strongly with those of the western Baltic, the latter resembling populations from marine habitats of the North Sea. Associated with a pronounced salinity gradient, the spatial heterogeneity in gene-pool structure is indicated by steep clines of allele frequency changes in the area of the eastern Danish isles. The adaptive significance of the observed allozymic variation is suggested. From genetic distance estimates, the subdivision of population structure is discussed in relation to the significant amount of differentiation detected within Mytilus populations to date and to the evolutionary time required for the divergence of Baltic mussel populations. The allozymic data provide evidence for the genetic distinctiveness of mussels from the low-salinity areas of the Baltic. Their position at the specific or subspecific level of classification requires further consideration.
\end{abstract}

\section{INTRODUCTION}

In recent years, results from enzyme electrophoresis have shown that mussel (Mytilus edulis L.) populations, once considered to be genetically homogeneous, are in fact genetically differentiated into distinct races or forms (Skibinski et al., 1980, 1983; Gosling, 1984; Koehn et al., 1984). On the basis of such differentiation, Koehn et al. (1984) have suggested that there may in fact be two distinct species of Mytilus distributed throughout the Atlantic Canadian Provinces of N. Canada. In an earlier study of mussel populations in the same area, Gartner-Kepkay et al. (1983) suggested that the observed differentiation in genetic constitution between localities was caused by selective effects of small environmental changes - particularly salinity - acting on a more or less genetically homogeneous spawning stock. Which of these two interpretations is the correct one remains to be seen.

In the British Isles - the only area in Europe where the genetics of Mytilus has been extensively surveyed - significant genetic differentiation has been observed both on a 
micro- and macrogeographic scale. Such differentiation is largely due to the presence of the Mediterranean mussel Mytilus galloprovincialis Lmk. on the Atlantic coasts of western Europe; here it is found intermixed with $M$. edulis in varying proportions. Evidence from electrophoretic analyses has indicated that the two forms of mussel are closely related; and everywhere the two are found together they hybridise and in some areas e.g. the Atlantic coasts of Ireland, parts of Scotland and NE England, intergradation between them is extensive (Skibinski et al., 1978; Skibinski \& Beardmore, 1979; Gosling \& Wilkins, 1981).

Outside of the British Isles there is a notable lack of published information on the genetics of mussels on Eastern Atlantic coasts. In a single report (Theisen, 1978), largescale genetic differentiation was observed between North Sea and Kattegat $M$. edulis and mussels sampled from a small area of the Baltic. Although salinity was cited as being the most likely selective agent maintaining the observed genetic differences there is the possibility that mussels in the Baltic could be a different race or ecotype compared to those distributed in the North Sea.

The Baltic Sea, an enclosed basin connected to the North Sea by the Kattegat, is the largest expanse of brackish water in the world, covering an area of $420000 \mathrm{~km}^{2}$. A great influx of river water and surface runoff causes a limited outflow of surface water into the North Sea, whereas a deeper countercurrent of more dense salt water moves into the Baltic. The hydrographical conditions are characterised by the absence of tidal currents and reduced salinity levels. The lowest are in the northern part at the head of the Bothnian Bay and the Gulf of Finland, while salinity increases gradually towards the southern Baltic Proper and western part, the Belt Sea (Fig. 1). The Baltic Sea exhibits pronounced salinity and temperature stratifications which show considerable regional and seasonal differences. Detailed accounts on its physical, chemical and biological oceanography have been presented by Voipio (1981). The importance of salinity as a factor in the distribution of organisms, as well as the specific ecological and physiological features of brackish-water animals have been outlined by Remane \& Schlieper (1971).

In many animal species the adaption to brackish-water conditions such as those in the Baltic has created considerable differences between populations living in this particular environment and those occurring in seawater. Mussels and several other bivalves reveal a reduction in body size, growth and length of life with decreasing ambient salinity levels. The reduction in size is most marked in molluscs: maximum body length of $M$. edulis at $5 \% \mathrm{~S}$ is about $1 / 3$ of that reached at $30 \%$ (Remane \& Schlieper, 1971). Also, a reduction of calcareous skeletons can be observed. Bivalves may develop shells which are considerably thinner compared to those of individuals distributed in fully marine areas. In addition to modifications of morphological and meristic characters, changes in vertical distribution, reproductive performance, and physiological capacities can also be observed.

In this paper we report the results of electrophoretic comparisons of Baltic Sea Mytilus with $M$. edulis from the North Sea and Atlantic coast of Ireland and with $M$. galloprovincialis from the Atlantic coast of Portugal. The present study covers a wide distribution area of Mytilus, ranging as far as the Gulf of Finland. Based on the allelic distribution patterns at 6 polymorphic loci, this analysis complements and extends the work of Theisen (1978), who investigated allozymic variation at 3 loci in mussel populations, particularly from Danish shores in the western Baltic. 


\section{MATERIALS AND METHODS}

Samples of Baltic mussels were obtained from several localities on the Finnish, Swedish, German and Danish coast (Fig. 1). They cover a wide geographic range of the Baltic Sea and include different salinity levels. The collecting sites and approximate surface salinities were as follows: Tvärminne (T) 5-6\%, Västervik (Vk) 5-6\%, Kåseberga (K) $9-10 \%$, Niendorf (N) $15 \%$, Vejle (V) $20 \%$. For comparison, populations from Helgoland Island $(\mathrm{H})$, North Sea $32 \%$, Galway, Ireland (G) 20-25\% and Albufeira, Portugal (A), Atlantic Ocean $36 \%$, were also studied.

Mussels of different size classes were collected by hand from various substrates, e.g. sublittoral or intertidal rocks and seaweeds. Some samples were maintained in the laboratory at $15^{\circ} \mathrm{C}$ in tanks filled with habitat water or in water corresponding to habitat salinity, while most were deep-frozen at $-70^{\circ} \mathrm{C}$ for a maximum period of 6 months prior to electrophoretic analysis.

A small piece of hepatopancreas and adductor muscle was removed from each individual, homogenised in $0.1 \mathrm{M}$ Tris $\mathrm{HCl}, \mathrm{pH} 8.0$ and centrifuged at $20000 \times \mathrm{g}$ for $4 \mathrm{~min}$. The supernatant of each sample was taken for vertical starch-gel electrophoresis; for comparison, horizontal electrophoresis was also applied. The buffer systems used were as follows: Tris-citrate (TC) buffer pH 7.3 (Ayala et al., 1972), Tris-borate EDTA buffer pH 9.0 (TBE) buffer (cf. Bulnheim \& Scholl, 1981), histidine-citrate (HC) buffer pH 7.0 (Ward \& Beardmore, 1977) and Tris-maleate (TM) buffer pH 7.4 (Spencer et al., 1964). The following enzymes were investigated in detail: phosphoglucose isomerase (PGI, EC 5.3.1.9), phosphoglucomutase (PGM, EC 2.7.5.1), leucine aminopeptidase (LAP, EC 3.4.11.-), octopine dehydrogenase (ODH, EC 1.5.1.11), esterase-D (EST-D, EC 3.1.1.1), and aminopeptidase (AP, EC 3.4.1.2). The Lap and Ap loci examined by us are equivalent to the Lap-2 and Ap loci of Skibinski et al. (1983). In addition, glutamate-oxalacetate transaminase (GOT, EC 2.6.1.1), including two isozymes, and mannose phosphate isomerase (MPI, EC 5.3.1.8) were assayed. Table 1 presents the buffer systems and staining procedures used in the screening of loci.

Table 1. Enzymes detected electrophoretically, symbols of loci scored, gel-buffer systems and staining procedures used in the analysis of Mytilus populations ("indicates agar overlay method, + paper overlay method)

\begin{tabular}{|c|c|c|c|}
\hline Enzymes & Locus & $\begin{array}{c}\text { Buffer } \\
\text { systems }\end{array}$ & Reference for assays \\
\hline Aminopeptidase & $A p$ & TC & Shaw \& Prasad (1970)* \\
\hline Esterase-D & Est-D & $\mathrm{HC}, \mathrm{TM}$ & Ahmad et al. (1977) \\
\hline Glutamate-oxaloacetate & Got-1 & $\mathrm{TC}, \mathrm{TM}$ & Modified after Scholl \\
\hline transaminase & Got-2 & & et al. (1978) \\
\hline Leucine aminopeptidase & Lap-2 & TBE, TM & Murdock et al. (1975) \\
\hline Mannosephosphate isomerase & $M p i$ & TBE & Harris \& Hopkinson (1976) ${ }^{*}$ \\
\hline Octopine dehydrogenase & Odh & TC, TM & Beaumont et al. (1980) \\
\hline Phosphoglucose isomerase & $P g i$ & $\mathrm{TC}, \mathrm{TM}$ & $\begin{array}{l}\text { Scholl et al. }(1978)^{*} \\
\text { Scopes }(1968)^{+}\end{array}$ \\
\hline Phosphoglucomutase & Pgm & $\mathrm{HC}, \mathrm{TM}$ & $\begin{array}{l}\text { Harris \& Hopkinson }(1976)^{*} \\
\text { Scopes }(1968)^{+}\end{array}$ \\
\hline
\end{tabular}



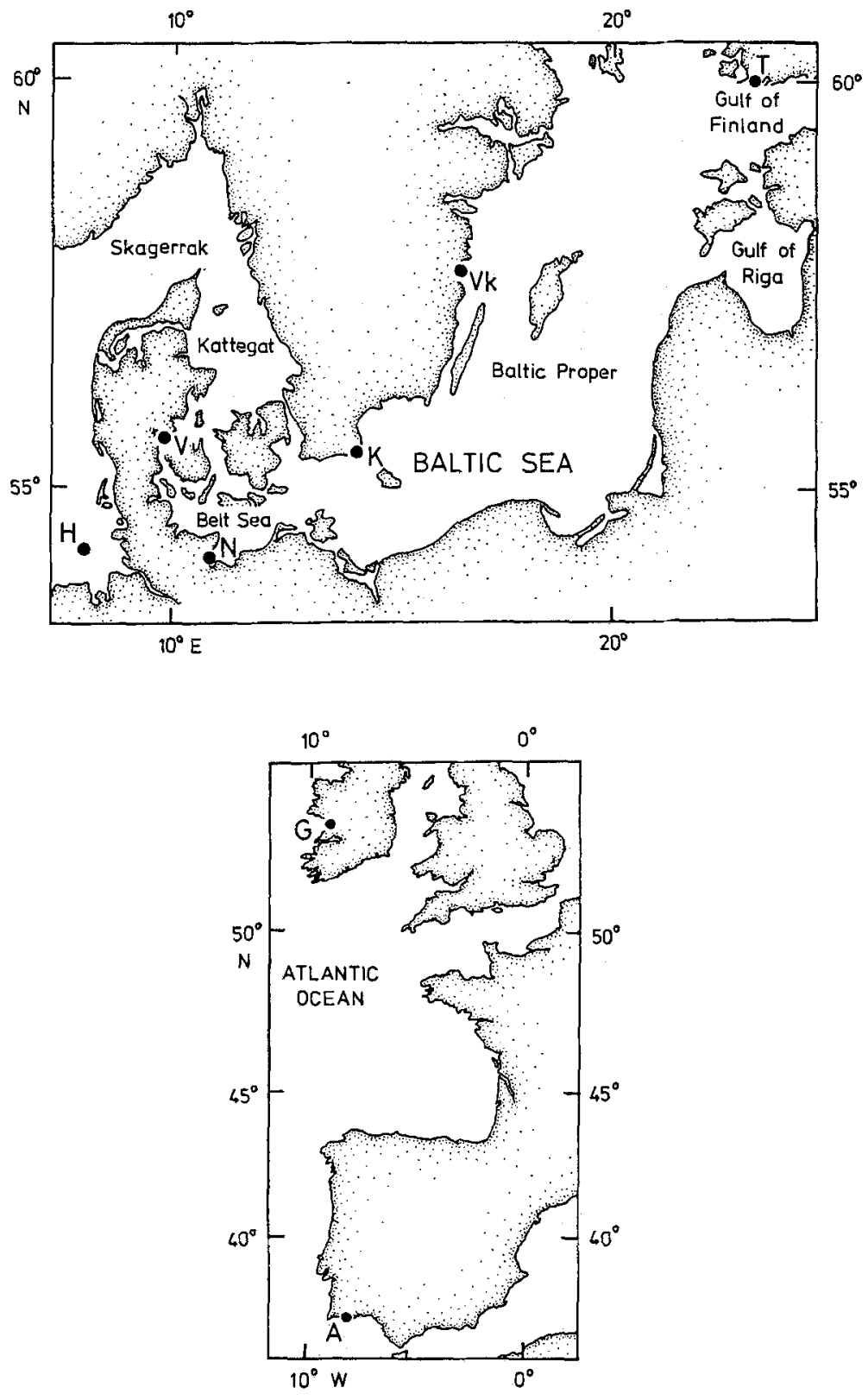

Fig. 1. Mussel sampling localities in the Baltic and North Sea (above): $T=$ Tvärminne (Finland), Vk = Västervik (Sweden), K = Kåseberga (Sweden), $N=$ Niendorf (F.R.G.), V = Vejle (Denmark), $\mathrm{H}=$ Helgoland (F.R.G., North Sea). Sampling localities in the eastern Atlantic (below): $\mathrm{G}=$ Galway (Ireland), A = Albufeira (Portugal) 
In comparing different populations, the electrophoretic mobility was assessed in relation to individuals from the Irish (Galway) population. Products of loci were numbered in order of increasing anodal mobility. Alleles for each locus were designated by their mobilities (in $\mathrm{mm}$ ) relative to the mobility of the most common allele - designated 100 - in the reference population.

The extent of genetic differentiation between populations was estimated according to the measures introduced by Nei (1972). Genetic identity (I) and genetic distance (D) along with the standard error of $D\left(s_{D}\right)$ were calculated among all pairs of populations averaged over all of the loci analysed as well as for each locus separately.

\section{RESULTS}

A total of 8 populations of Mytilus were examined in this study (Fig. 1). Allele frequencies, observed $\left(\mathrm{H}_{0}\right)$ and expected $\left(\mathrm{H}_{\mathrm{e}}\right)$ heterozygosities for the 6 loci scored in each population are presented in Table 2 .

\section{Phosphoglucose isomerase}

Between 4 and 6 alleles have been observed at the Pgi locus in Baltic populations of Mytilus. Outside of the Baltic there is increased genetic variability, with numbers of alleles per population ranging between 6 and 8. Genotypic frequencies in all populations examined were in good agreement with Hardy-Weinberg predictions. Pgi ${ }^{87}$ was the most common allele in Baltic populations, with frequencies $>0.84$. This allele probably corresponds to $P g i^{83}$ of Theisen (1978). Outside of the Baltic the two most common alleles were $P g i^{90}$ and $P g i^{100}$ with $P g i^{93}$ at a frequency between 0.06 and 0.12 in $M$. edulis and at a higher frequency $(0.25)$ in $M$. galloprovincialis. Alleles $\mathrm{Pgi}^{90}, \mathrm{Pgi}^{93}$ and $\mathrm{Pgi}{ }^{100}$ probably correspond to alleles of similar mobility cited in Skibinski et al. (1983). Allele frequencies in the Galway ( $M$. edulis) and Portuguese ( $M$. galloprovincialis) samples bear a close similarity to those observed for British ( $M$. edulis) and Gibraltar (M. galloprovincialis) populations respectively (cf. Skibinski et al., 1983).

\section{Phosphoglucomutase}

At the highly polymorphic Pgm locus 6 to 7 alleles have been observed in Baltic populations of Mytilus. Once again, populations outside of the Baltic Sea exhibited increased genetic variability, with the numbers of alleles varying between 8 and 10 . Large and significant deficiencies of heterozygotes have been observed in 2 of the 3 populations surveyed from the Baltic Proper; in the case of the Baltic populations two (Niendorf and Vejle) exhibited a significant deficit of heterozygotes while the Vejle sample showed a non-significant excess. In the case of the Niendorf and Vejle samples many alleles at low frequencies were observed. It was therefore necessary to pool alleles in order to compute the $\chi^{2}$ value. There is evidence that this policy has generated a significant $\chi^{2}$ value in the Niendorf sample, which is not supported by the $H_{o}$ and $H_{e}$ values calculated from the unpooled genotypic data. The Albufeira sample of $M$. galloprovincialis exhibited an overall deficiency of heterozygotes relative to HardyWeinberg expectations, while in the case of the Galway population, where $\mathrm{H}_{\mathrm{o}}$ and $\mathrm{H}_{\mathrm{e}}$ 


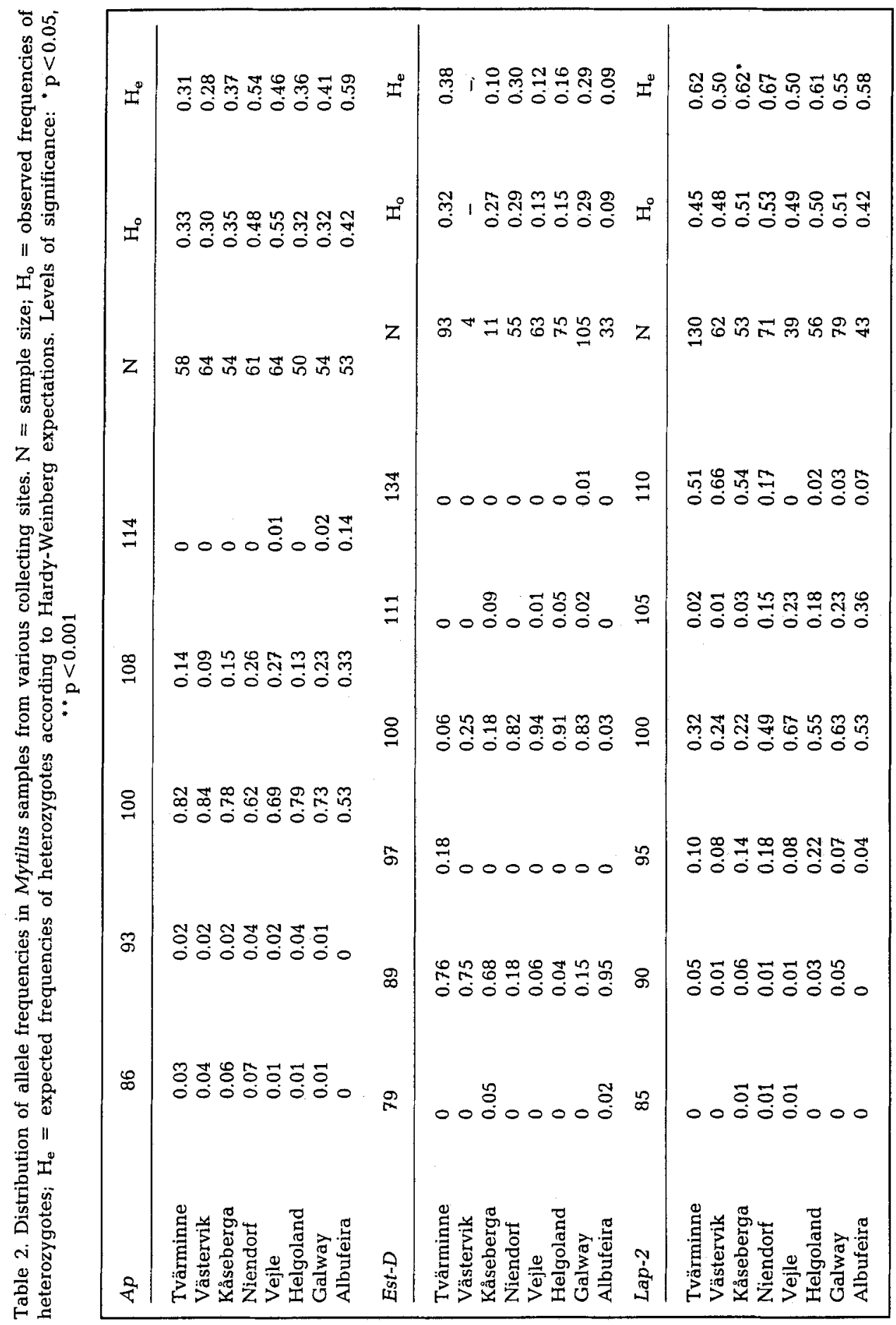




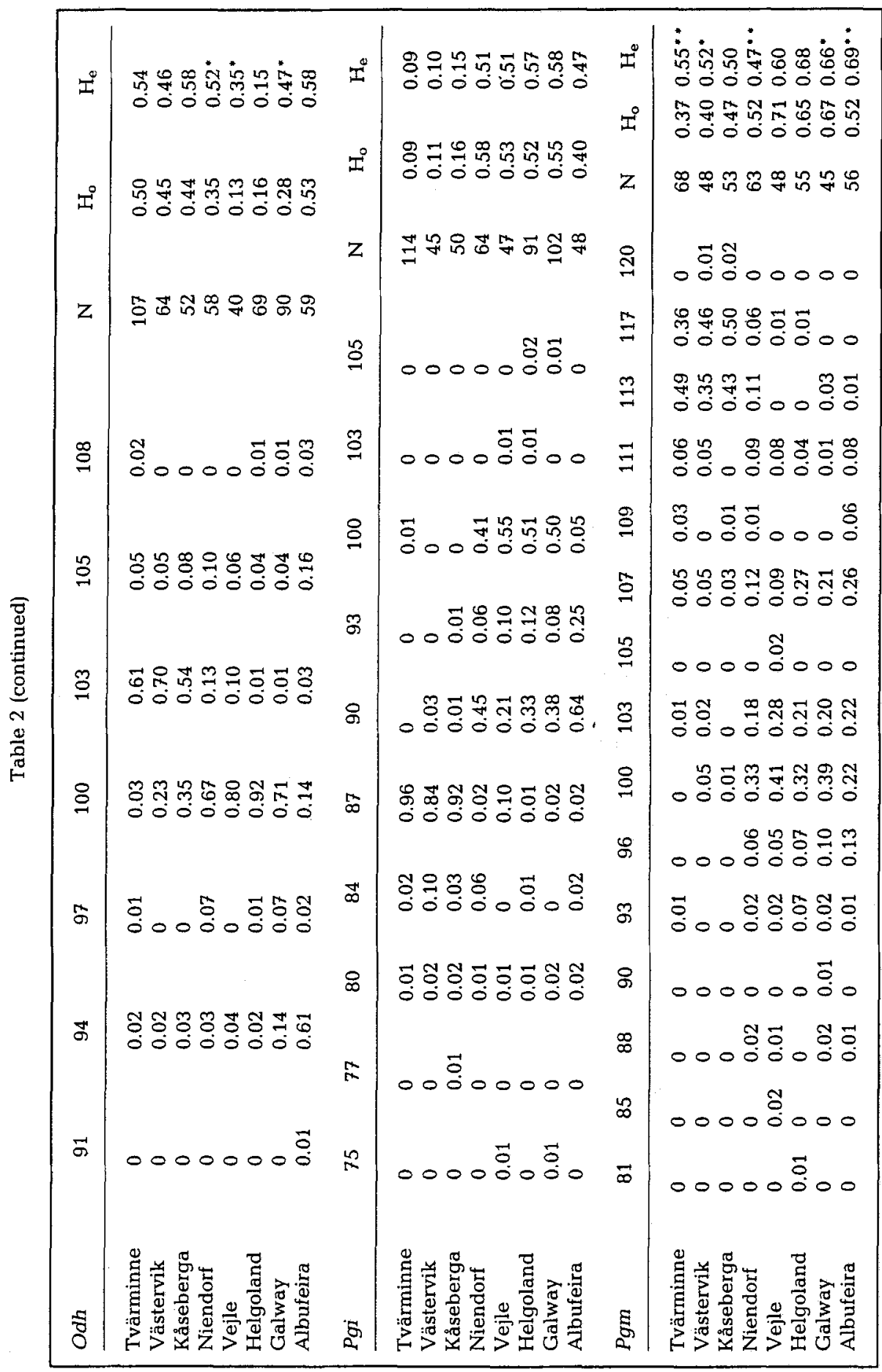


values were almost identical, the significant $\chi^{2}$ value observed for this sample was mainly due to the significant deficit of $100 / 103$ heterozygotes.

In the Baltic populations, $P g m^{113}$ and $P g m^{117}$ were the two common alleles, while outside of the Baltic the most common alleles in $M$. edulis and $M$. galloprovincialis were $\mathrm{Pgm}^{100}, \mathrm{Pgm}^{103}$ and $\mathrm{Pgm}^{107}$. It is difficult to compare the results for this locus with results obtained by Skibinski et al. (1983) for British M. edulis and Mediterranean M. galloprovincialis as well as by Theisen (1978) for Baltic and North Sea Mytilus. We believe that a greater number of alleles has been resolved by us at this locus using a histidine-citrate buffer, pH 7.0, on a vertical electrophoretic system. Beaumont \& Beveridge (1983) have also noted that in $M$. edulis the number of $P g m$ alleles resolved depends on the $\mathrm{pH}$ of the Tris-maleic electrode buffer on horizontal starch gel electrophoresis. They observed 6 alleles at this locus using $\mathrm{pH} 7.4$ and 9 alleles at $\mathrm{pH}$ 6.0. In the present study, while the majority of individuals was analysed on vertical starch gel electrophoresis using a histidine-citrate buffer, $\mathrm{pH} 7.0$, a small sample of mussels was analysed from the Galway and Helgoland populations on a horizontal electrophoretic system using a Tris-maleic buffer, pH 7.4. Only 5 alleles $\left(\mathrm{Pgm}^{93}, \mathrm{Pgm}^{96}, \mathrm{Pgm}^{100}, \mathrm{Pgm}^{107}\right.$ and $\left.\mathrm{Pgm}^{117}\right)$ were observed in a sample of 30 individuals from the Helgoland population while $7\left[\mathrm{Pgm}^{93}, \mathrm{Pgm}^{96}, \mathrm{Pgm}^{100}\right.$, $\mathrm{Pgm}^{103}$ (very low frequency), $\mathrm{Pgm}^{107}, \mathrm{Pgm}^{111}$ and $\mathrm{Pgm}^{113}$ ] were observed in a sample of 64 individuals from the Galway population. The rare alleles $\mathrm{Pgm}^{88}$ and $\mathrm{Pgm}^{90}$ in the Galway sample and $\mathrm{Pgm}^{81}$ (rare) and $P g m^{103}$ in the sample from Helgoland were not detected using this buffer system (Table 2).

Allele frequencies (using the Tris-maleic system) were in close agreement with allele frequencies observed for this locus in Irish and British populations of $M$. edulis by Gosling \& Wilkins (1981) and Skibinski et al. (1983) respectively. On the Tris-maleic system, $\mathrm{Pgm}^{93}, \mathrm{Pgm}^{96}, \mathrm{Pgm}^{100}$ and $\mathrm{Pgm}^{107}$ would appear - from'a comparison of allele frequencies - to be equivalent to $\mathrm{Pgm}^{92}, \mathrm{Pgm}^{96}, \mathrm{Pgm}^{100}$ and $\mathrm{Pgm}^{104}$ of Skibinski et al. (1983). Comparing the results obtained, using the histidine-citrate vertical and Tris-maleic horizontal systems, we believe that the common electromorph Pgm ${ }^{100}$ on the Tris-maleic system is resolved into 2 electromorphs, $\mathrm{Pgm}^{100}$ and $\mathrm{Pgm}^{103}$, on the histidine-citrate system with the frequency of $\mathrm{Pgm}^{103}$ varying between 0.18 and 0.28 in non-Baltic samples. In the Baltic populations, it would appear, from a comparison of allele frequencies, that $P_{g m}{ }^{113}$ and $P_{g m}{ }^{117}$ are equivalent to alleles 3 and 2 respectively of Mytilus from Bornholm island (Theisen, 1978).

\section{Esterase-D}

Unlike the situation for the Pgi and Pgm loci, populations in the Baltic did not exhibit lower levels of genetic variability than non-Baltic populations at the Est-D locus. Numbers of electromorphs ranged between 2 and 4, with 1-2 common alleles in each of the 8 populations examined. Genotypic frequencies in all populations - with the exception of Västervik and Kåseberga, where numbers of individuals were too low for statistical analysis - were in good agreement with Hardy-Weinberg expectations. In the Baltic populations, Est- $D^{89}$ was the common allele at a frequency between 0.68 and 0.76 , while Est- $D^{97}$ - at a frequency of 0.18 in the Tvärminne sample - was not detected in the Västervik and Kåseberga populations, probably because of the small numbers of individuals analysed at these sites. Outside of the Baltic, Est- $D^{100}$ was at a high frequency of $>0.82$ in $M$. edulis. This was also shown by Fevolden \& Garner (1986) in mussel 
populations from Oslofjorden in southern Norway. However, in the sample of M. galloprovincialis from Portugal, Est- $D^{89}$ was the common electromorph $(0.95)$ and Est-D ${ }^{100}$ was at a very low frequency of 0.03 . Our results from Est- $D$ frequencies are in good agreement with frequencies observed by Skibinski et al. (1983) for $M$. edulis and M. galloprovincialis. It would appear from a comparison of our results that the designation of allelic variants used in the present study corresponds to that introduced by Skibinski et al. (1983) for this particular locus.

\section{Aminopeptidase}

A total of five electromorphs was observed at the Ap locus, although only two alleles were common in all populations. The rare allele $A p^{114}$ was detected in two $M$. edulis populations only (Table 2). In contrast to all mussel populations studied, $A p^{86}$ and $A p^{93}$ were not present in the $M$. galloprovincialis sample. $A p^{100}$ was the most common electromorph in all populations examined. The pattern of allelic variation observed at this locus in samples from high salinity collecting sites is very similar to that reported for the British Isles by Skibinski et al. (1980). All samples were in good agreement with HardyWeinberg predictions.

\section{Leucine aminopeptidase}

The Lap-2 locus examined by us corresponds to Lap-2 of Skibinski et al. (1980) and to aminopeptidase-1 of Koehn \& Gaffney (1984). Altogether, six alleles were observed at the Lap-2 locus. Among these, Lap- $2^{90}$ and particularly Lap- $2^{85}$ represent rare alleles, both of which were absent in the sample from Portugal. Allele frequencies of Skibinski et al. (1980) for British mussels were similar to those observed at this locus for the Helgoland and Galway samples. They also observed five alleles ranging from $L a p-2^{90}$ to $L a p-2^{110}$. When our results for Baltic and North Sea mussels are compared to those of Theisen (1978) for the same area, it appears from the similarity in allele frequencies that alleles $1,2,3,4$ and 5 of Theisen (1978) are equivalent to Lap- $2^{90}, L a p-2^{95}, L a p-2^{100}, L a p-2^{105}$ and $L a p-2^{110}$ in the present investigation. In a more recent analysis on North Sea mussels from Oslofjorden there is some uncertainty whether Lap-3 described by Fevolden \& Garner (1986) is identical with the Lap-2 locus of the present study. With the exception of the Kåseberga sample, where a significant deficiency of heterozygotes was observed, genotypic distributions in all other populations were in good agreement with HardyWeinberg expectations.

\section{Octopine dehydrogenase}

Excluding the Portuguese sample, six electromorphs were detected at the Odh locus in all populations. An additional allele $\left(O d h^{91}\right)$ occurred only in the $M$. galloprovincialis sample at very low frequency. A large amount of genetic heterogeneity in allele frequencies was observed between the different populations analysed, with the frequency of the common electromorph $O d h^{100}$ ranging between 0.23 (Västervik) and 0.92 (Helgoland). In the $M$. galloprovincialis sample the frequency of $\mathrm{Odh}^{94}$ was relatively high (0.61) in comparison with its frequency in the other populations. While this allele is not completely diagnostic on an individual basis, its frequency permits us to discern between $M$. edulis and $M$. galloprovincialis at the population level. Odh as well as Est-D have been used as partially diagnostic loci in separating mixed populations of the two 
forms of mussels, M. edulis and M. galloprovincialis, from S.W. England (Skibinski, 1983). However, the Odh locus - in contrast to Pgi, Pgm and Lap-2 - provided little discrimination among populations of Mytilus analysed from the east coast of N. America (Koehn et al., 1984).

Significant deficiencies of heterozygotes were observed in the Niendorf, Vejle and Galway populations. Such deficits have been reported for $M$. edulis from Long Island Sound (Koehn \& Gaffney, 1984) and have also been observed in Irish populations of this species (Gosling, unpublished data).

\section{Other loci}

Two additional gene-enzyme systems were investigated in the course of the present study, glutamate oxaloacetate transaminase (Got-1 and Got-2) and mannosephosphate isomerase ( $M p i)$. At the Got-1 locus, the frequency of the common allele ranged between 0.91 and 0.99 in the eight populations analysed while there was even less variation in the frequency of the common Got-2 allele between populations $(0.96-0.99)$. These loci therefore were of little value in discriminating between populations. There were some technical difficulties in staining for the $M p i$ locus and therefore only small numbers of individuals could be reliably scored from the majority of the eight populations. However, this locus does appear to be partially diagnostic in separating $M$. edulis populations (Vejle, Helgoland and Galway) from the $M$. galloprovincialis population with the frequency of $\mathrm{Mpi}^{96}$ high in $M$. galloprovincialis and low in $M$. edulis and the opposite situation for $\mathrm{Mpi}^{100}$. Allele frequencies in the remaining Baltic populations were somewhat intermediate.

\section{Levels of genetic similarities}

A comparison of the allele frequency distribution at the six loci investigated in detail indicates that there is significant variation in the genetic structure of mussel populations in the Baltic area. The high degreee of allozymic variation which was detected at most of the loci analysed is also reflected in the coefficients of genetic identity and genetic distance respectively (Nei, 1972) listed in Table 3.

Averaged over the six loci, a high degree of genetic similarity between the Finnish population from Tvärminne and the two Swedish populations from Västervik and Kåseberga with $\bar{I}$ values very close to 1 can be noted. However, there is a pronounced difference between these populations and those from Niendorf and Vejle - the two remaining Baltic populations - with $\bar{I}$ values in the range 0.35-0.51. As is evident from Table 2, abrupt spatial changes in allele frequency (observed for Pgi, Pgrn, Odh, Est-D and Lap-2) occur over relatively short distances (ca $200 \mathrm{~km}$ ).

Populations of $M$. edulis outside of the Baltic Sea (Helgoland and Galway) were, not surprisingly, even more genetically different from those in the Baltic Proper with $\bar{I}$ values in the range $0.31-0.43 . M$. galloprovincialis exhibits a gene-pool structure which is different from all of the remaining populations investigated. This is reflected by $\bar{I}$ values in the range $0.47-0.60$.

In addition, calculations of Nei's coefficients of genetic identity were made for each of the six loci separately. These estimates revealed the following order of increasing genetic variation: Ap, Lap-2, Est-D, Odh, Pgm and Pgi. 
Table 3. Coefficients of mean genetic identity $\left(\bar{I}_{\text {; }}\right.$ above diagonal) and mean genetic distance $(\bar{D}$ $\pm s_{D}$ below diagonal between the Mytilus populations examined. Calculations (according to Nei, 1972) are based on the gene products of 6 polymorphic loci (Ap, Est-D, Lap-2, Odh, Pgi, Pgm)

\begin{tabular}{|c|c|c|c|c|c|c|c|c|c|}
\hline Sample & & $T$ & Vk & K & $N$ & V & $\mathrm{H}$ & $\mathrm{G}$ & A \\
\hline Tvärminne & & - & 0.97 & 0.97 & 0.42 & 0.35 & 0.31 & 0.35 & 0.49 \\
\hline Västervik & Vk & $\begin{array}{r}0.03 \\
\pm 0.07\end{array}$ & - & 0.98 & 0.51 & 0.43 & 0.41 & 0.43 & 0.49 \\
\hline Kåseberga & $\mathrm{K}$ & $\begin{array}{r}0.04 \\
\pm 0.08\end{array}$ & $\begin{array}{r}0.02 \\
\pm 0.05\end{array}$ & - & 0.51 & 0.44 & 0.42 & 0.44 & 0.47 \\
\hline Niendorf & $\mathrm{N}$ & $\begin{array}{r}0.88 \\
\pm 0.48\end{array}$ & $\begin{array}{r}0.67 \\
\pm 0.40\end{array}$ & $\begin{array}{r}0.70 \\
\pm 0.40\end{array}$ & - & 0.96 & 0.96 & 0.97 & 0.59 \\
\hline Vejle & V & $\begin{array}{r}1.06 \\
\pm 0.56\end{array}$ & $\begin{array}{r}0.84 \\
\pm 0.47\end{array}$ & $\begin{array}{r}0.83 \\
\pm 0.47\end{array}$ & $\begin{array}{r}0.04 \\
\pm 0.08\end{array}$ & - & 0.98 & 0.98 & 0.50 \\
\hline Helgoland & $\mathrm{H}$ & $\begin{array}{r}1.17 \\
\pm 0.61\end{array}$ & $\begin{array}{r}0.90 \\
\pm 0.49\end{array}$ & $\begin{array}{r}0.88 \\
\pm 0.48\end{array}$ & $\begin{array}{r}0.04 \\
\pm 0.08\end{array}$ & $\begin{array}{r}0.03 \\
\pm 0.07\end{array}$ & - & 0.98 & 0.49 \\
\hline Galway & G & $\begin{array}{r}1.04 \\
\pm 0.55\end{array}$ & $\begin{array}{r}0.84 \\
\pm 0.47\end{array}$ & $\begin{array}{r}0.83 \\
\pm 0.47\end{array}$ & $\begin{array}{r}0.03 \\
\pm 0.07\end{array}$ & $\begin{array}{r}0.02 \\
\pm 0.06\end{array}$ & $\begin{array}{r}0.02 \\
\pm 0.06\end{array}$ & - & 0.60 \\
\hline Albufeira & A & $\begin{array}{r}0.71 \\
\pm 0.42\end{array}$ & $\begin{array}{r}0.72 \\
\pm 0.42\end{array}$ & $\begin{array}{r}0.75 \\
\pm 0.43\end{array}$ & $\begin{array}{r}0.54 \\
\pm 0.34\end{array}$ & $\begin{array}{r}0.69 \\
\pm 0.41\end{array}$ & $\begin{array}{r}0.23 \\
\pm 0.42\end{array}$ & $\begin{array}{r}0.51 \\
\pm 0.33\end{array}$ & - \\
\hline
\end{tabular}

\section{DISCUSSION}

Owing to its ecological and economic importance, wide distribution, and easy availability, the biology of mussels has received much attention and they are, without doubt, the most intensively studied marine invertebrate to-date.

Since the introduction of electrophoretic techniques, the population genetics and biochemical systematics of Mytilus have been the subject of numerous investigations (for reviews cf. Koehn, 1983; Gosling, 1984). A large body of information on micro- and macrogeographic variation has accumulated from several polymorphic gene-enzyme systems studied in mussel populations from both North America (Koehn et al., 1976, 1984; Levinton \& Suchanek, 1978; Gartner-Kepkay et al., 1980, 1983) and selected areas of Europe (Theisen, 1978; Murdock et al., 1979; Gosling \& Wilkins, 1981; Skibinski et al., 1983; Fevolden \& Garner, 1986).

As outlined in the preceding section, our electrophoretic survey of Baltic Mytilus which covered a very wide area of its range in this sea revealed both considerable interpopulation genetic heterogeneity and homogeneity. The comparisons made with samples of $M$. edulis and $M$. galloprovincialis from marine localities allowed us to identify and quantify the extent of genetic differentiation observed as well as to assess the uniqueness of the gene-pool structure of mussels from the Baltic Proper and the Gulf of Finland.

Owing to the absence of major predators and competitors, Mytilus represents an important faunal component of benthic communities in the Baltic. The dense populations which consist of dwarfed individuals dominate hard bottoms, indicating strong intraspecific competition for food and space. The large annual variations which occur in the Baltic with regard to temperature and food abundance give rise to a more pronounced 
annual pattern in the reproductive cycle than is recorded in other seas. Only one spawning period occurs in spring. The planktonic larval period requires 5 to 6 weeks followed by settlement of the larvae during early summer (Kautsky, 1982). The latter takes place in excess of the demands for maintaining population size. From the pool of competitively suppressed non-growing individuals recruitment is possible throughout the year, thus stabilizing local populations. Similar to Mytilus spp. occurring in other marine areas, Baltic mussels exhibit high fecundity and considerable dispersal potential during their pelagic life.

Mussels are distributed in a wide area of the Baltic. In the Gulf of Bothnia and the Gulf of Finland their range is limited by salinities of ca $4-4.5 \%$. The innermost collecting sites of Mytilus in these low-salinity basins have been mapped by Segerstråle (1957, p. 773).

The euryhaline mussels are osmoconformers, i.e. they are able to alter extracellular osmoconcentration in response to environmental salinity variation. Tedengren \& Kautsky (1986) suggested that the low growth increment and small maximum size of Baltic individuals is caused by a less favourable energy metabolism due to the osmotic stress at low salinities. The O:N ratio (calculated from respiration and excretion) which has been used to describe the physiological status of bivalves (Widdows, 1978) is consistently lower in Baltic mussels as compared to those from the North Sea when exposed to ambient salinities. This parameter decreases with lowered salinities and vice versa. The correlation established between $\mathrm{NH}_{4}-\mathrm{N}$ excretion and environmental salinity levels indicates that excretion is associated with osmotic adjustments by utilizing free amino acids for intracellular volume regulation. Thus, the regulation of intracellular concentrations of amino acids resulting from the stress imposed by low salinities is an important physiological mechanism for maintaining the life processes of mussels in brackish-water environments.

The interaction of environmental factors with biochemical characteristics of aminopeptidase-I, the enzymatic product of the Lap-2 locus, has been demonstrated by several studies (Koehn, 1978; Koehn \& Immerman, 1981; Koehn \& Siebenaller, 1981). This dimer, associated with protein catabolism, is involved in the degradation of intracellular protein to supply the cytosolic free amino acid pool. Mussel populations which encounter different salinities display differences in the activity of aminopeptidaseI and other lysosomal enzymes (Moore et al., 1980). This variation in biochemical function was shown to be Lap-2 genotype-dependent. The differences in the catalytic efficiencies among Lap-2 genotypes indicate the physiological consequences of the diversity at the biochemical genetic level. The correlation detected between allozymic variants and specific lysosomal enzyme activity has been considered as evidence of the adaptive significance of enzyme polymorphism. From the analysis of the Lap-2 polymorphism one may conclude that environmental factors maintain the genetic variation which reflects the action of different forces of natural selection directed at this particular locus.

What conclusions can be drawn in the context of these findings from the study of the Lap-2 locus in Baltic mussels? For the purpose of comparing results from various authors, Skibinski et al. (1983, p. 169) made attempts to clarify the nomenclature of differently designated alleles. Following their conclusions, the alleles $L a p-2^{95}, L a p-2^{100}, L a p-2^{105}$ and $L a p-2^{110}$ of this study correspond to $L a p^{94}, L_{a p}{ }^{96}, L a p^{98}$ and $L a p^{100}$ referred to by Koehn et al. (1976). Lap-2 $2^{100}$ has the highest frequency in M. edulis from the British Isles (Skibinski 
et al., 1983). This situation is also found in Irish and North Sea mussels as demonstrated by the present study. On the east coast of N. America, the frequency of the common allele Lap $-2^{94}$ is highest and invariant from Virginia to Cape Cod but declines abruptly and remains less common throughout the Gulf of Maine. At the eastern end of Long Island Sound its frequency changes from 0.55 in oceanic populations to 0.12 in estuarine populations over a distance of less than $30 \mathrm{~km}$ (Koehn et al., 1976). These observations indicate considerable variation in allele frequencies in relation to environmental salinity. As documented in Table 2, similar changes in allozyme variation were evident at the Lap-2 locus, exhibiting a clinal shift between mussel populations from southern Sweden and the western Baltic coast. Similar to observations made by Koehn et al. (1976), the geographic pattern in the Baltic shows frequency changes of the common electromorph Lap- $2^{100}$ from 0.67 to about, 0.25 , i.e. in a direction toward populations inhabiting more dilute brackish-water environments.

When compared with the other enzyme loci under consideration, a similar trend in allele frequency changes can be seen: more or less steep clinal shifts occur, resulting in divergent population genetic structures between mussels from the Belt Sea and those from the Baltic Proper, including the Gulf of Finland. The abrupt frequency changes are most conspicuous at the Pgi locus and are followed by Pgm, Odh, Est-D and Lap-2 in order of decreasing variation. By contrast, allele frequencies at the Ap locus are rather invariant over the survey area. These results are very much in line with those of Koehn et al. (1984) where three of these loci (Lap-2, Pgi and $P g m$ ) have been successfully used to distinguish three geographically separated population subsets on the Atlantic coast of N. America.

The discordant patterns of genetic variation established in Baltic mussel populations indicate that selective forces of different magnitudes may affect the loci under investigation. The above-reported results and those on Mytilus samples from collecting sites on the east coast of $\mathrm{N}$. America lead to the conclusion that the significant variation in allele frequencies appears to be generated and maintained by the salinity gradient present in the Baltic Sea.

In the large area between the Åland Islands at the northern boundary of the Baltic Proper and its transition to the Belt Sea near the Danish islands, surface salinity increases by only $2 \%$. This is reflected by a considerable genetic homogeneity among the three populations surveyed from Finland and Sweden. In the Øresund towards the Kattegat and along the German coast, there is a progressive increase in salinity. Apart from seasonal salinity variations, which can be noted especially in the superficial layers, the shallow depths of the Sound $(7-8 \mathrm{~m})$ and Darss thresholds $(16-18 \mathrm{~m})$ are boundaries between the more dilute waters of the Baltic Proper and the more saline waters of the Belt Sea.

The macrogeographic survey presented in this multi-locus study as well as the findings reported by Theisen (1978) suggest that the change of gene-pool structure is correlated - to some extent - with the location of the isohalines at 8 to $10 \% \mathrm{~S}$ which are closely associated with this shallow area of the Baltic. Theisen's results, based on a microgeographic investigation of allozymic variation at the Pgm, Pgi and Lap loci in mussel populations that had been collected on the Danish isles, indicate that significant allele frequency changes occur within short distances (ca $50 \mathrm{~km}$ ), particularly along the east coast of the islands Sjaelland, Møn and Falster. However, except for the approach 
made to determine the adaptive significance of the aminopeptidase-I polymorphism (cf. Koehn, 1983), the biochemical and physiological consequences of this allozymic variation are not known.

Nei's genetic identity values for populations within the Baltic Proper (Tvärminne, Västervik and Kåseberga) are high (Table 3 ) with mean values in the range 0.96-0.98, the range expected for conspecific populations of invertebrates (Ferguson, 1980). Mean $\bar{I}$ values for the western Baltic populations from Niendorf and Vejle and for the marine sites Helgoland and Galway are also high (0.96-0.98), suggesting that these four populations are conspecific also. However, when the two groups are compared, $\bar{I}$ values are in the range $0.31-0.51$. Genetic identity values of this order can be expected between sibling or even distinct species of invertebrates (Ferguson, 1980). Therefore, our results strongly suggest that mussels within the Baltic Proper are not in fact $M$. edulis, but constitute a different distinct species of the genus Mytilus or a subspecies of M. edulis. Further relevant studies are in progress.

The mean value of $T$ for the comparison of $M$. edulis (Galway) and the single $M$. galloprovincialis sample was 0.60 - a value which is very much lower than the value of 0.84, based on 16 loci, computed by Skibinski et al. (1980) for comparisons between $M$. edulis from S. Wales (UK) and M. galloprovincialis from Venice (Italy). Their value is similar to the mean values observed for comparisons between subspecies of other invertebrate taxa (Snyder \& Gooch, 1973; Ayala et al., 1974; Avise, 1976). We are aware that the number of loci examined by us, compared to other studies, is low and that the inclusion of a larger and less variant sample of loci would no doubt yield larger estimates of genetic identity. However, upgrading our genetic identity values by about 0.25 to take this into account, $I$ values for comparisons between samples from the Baltic Proper and the remaining $M$. edulis populations are still in the' range expected $(0.51-0.76)$ for comparisons between distinct species. In the only reported study of mussels from this area, Theisen (1978) observed large conspicuous discontinuities in Pgi, Pgm and Lap allele frequencies between populations from Bornholm island (close to Kåseberga) in the southern Baltic Proper and those from the Kattegat and North Sea area. There is no suggestion in Theisen's paper that mussels in the Baltic Proper are a different race, ecotype or subspecies of the large $M$. edulis species complex. Our report is therefore the first indication of the presence of a new, hitherto undescribed form of Mytilus in the low salinity area of the Baltic Sea.

The magnitude of genetic variation disclosed in the genetic composition of Baltic mussel populations is unique. The picture that has emerged contrasts with results obtained from other Baltic invertebrates: The distribution of allele frequencies at polymorphic enzyme loci studied in populations of Gammarus zaddachi, G. salinus (Bulnheim \& Scholl, 1981, 1982) and Idotea balthica (Bulnheim \& Fava, 1982; Bulnheim, 1984) did not exhibit clinal variation. On the contrary, the electrophoretic analysis of individuals collected from northern and western sites of the Baltic revealed relatively uniform patterns which, however, differ from those observed in North Sea populations. Unlike mussels, these euryhaline crustaceans are active osmoregulators when exposed to declining salinities.

The above-described results provide evidence that clinal divergence which may be considered a mode of speciation in the presence of pronounced environmental gradients (cf. Templeton, 1981) has lead to the geographic isolation of the mussel populations 
inhabiting the Baltic Proper and other areas of the northern Baltic Sea. With regard to the time scale involved in the microevolutionary changes that have occurred in low-salinity populations, a relatively short period comprising ca 7000 years must be taken into consideration. The events of the geological history and the changes of the hydrographic regimes during this period are well known for the Baltic Sea (cf. Winterhalter et al., 1981). After the last Ice Age, it has changed into a freshwater lake twice. Following the period of the "Ancylus Lake" (up to 5100 B. C.), during postglacial elevation of land and water levels, the salinity of the Baltic increased owing to the influx of seawater via the Kattegat. In the course of this "Littorina Period", which comprised approximately 3000 years, marine species invaded the Baltic and constituted a typically marine fauna. Following subsequent geological changes of the connection to the Kattegat, the salinity level of the Baltic gradually decreased again and marine species were repelled. The considerable discharge of freshwater resulted in the present brackish-water conditions which have existed without notable modifications for the past 2000 years. Probably, most of the pronounced microevolutionary changes in the genetic make-up of Baltic mussel populations have evolved during the last 4000 years. Similar to the explanation provided for estuarine variation at the Lap-2 locus in Mytilus (cf. Koehn, 1983), these processes of differentiation at the molecular level suggest the action of natural selection over time and space.

Acknowledgements. We are indebted to S. Bahns for technical assistance, H. Fröhlich for help with the final version of the manuscript, H. Geisler, B. Ibsen and M. Sturm as well as to the staff of the Tvärminne Zoological Station for aid in collecting mussel samples.

\section{LITERATURE CITED}

Ahmad, M., Skibinski, D. O. F. \& Beardmore, J. A., 1977. An estimate of amount of genetic variation in the common mussel Mytilus edulis. - Biochem. Genet. 15, 833-846.

Avise, J. C., 1976. Genetic differentiation during speciation. - In: Molecular evolution. Ed. by F. J. Ayala. Sinauer Ass., Sunderland, 106-122.

Ayala, F. J., Powell, J. R., Tracey, M. L., Mourao, C. A. \& Péres-Salas, S., 1972. Enzyme variability in the Drosophila willistoni group. IV Genic variation in natural populations of Drosophila willistoni. - Genetics 70, 113-139.

Ayala, F. J., Tracey, M. L., Barr, L. G., McDonald, J. F. \& Péres-Salas, S. , 1974. Genetic variation in natural populations of five Drosophila species and the hypothesis of the selective neutrality of protein polymorphisms. - Genetics 77, 343-384.

Beaumont, A. R. \& Beveridge, C. M., 1983. Resolution of phosphoglucomutase isozymes in Mytilus edulis L. - Mar. Biol. Lett. 4, 97-103.

Beaumont, A. R., Day, T. R. \& Gäde, G., 1980. Genetic variation at the octopine dehydrogenase locus in the adductor muscle of Cerastoderma edule (L.) and six other bivalve species. - Mar. Biol. Lett. $1,137-148$.

Bulnheim, H.-P., 1984. Biochemisch-genetische Untersuchungen zur Art- und Populationsdifferenzierung bei Amphipoden und Isopoden. - Zool. Beitr. 28, 349-368.

Bulnheim, H.-P. \& Scholl, A., 1981. Genetic variation between geographic populations of the amphipods Gammarus zaddachi and G. salinus. - Mar. Biol. 64, 105-115.

Bulnheim, H.-P. \& Fava, G., 1982. Colour polymorphism and genetic variation in Idotea balthica populations from the Adriatic Sea and Baltic Sea. - Genetica 59, 177-190.

Bulnheim, H.-P. \& Scholl, A., 1982. Polymorphism of mannose phosphate isomerase in North Sea and Baltic Sea populations of the amphipods Gammarus zaddachi and G. salinus. - Mar. Biol. 71, 163-166.

Ferguson, A., 1980. Biochemical systematics and evolution. Blackie, Glasgow, 194 pp. 
Fevolden, S. E. \& Garner, S. P., 1986. Population genetics of Mytilus edulis (L.) from Oslofjorden, in oil-polluted and non oil-polluted water. - Sarsia 71, 247-257.

Gartner-Kepkay, K. E., Dickie, L. M., Freeman, K. R. \& Zouros, E., 1980. Genetic differences and environments of mussel populations in the Maritime Provinces. - Can. J. Fish. aquat. Sci. 37, 775-782.

Gartner-Kepkay, K. E., Zouros, E., Dickie, L. M. \& Freeman, K. R., 1983. Genetic differentiation in the face of gene flow: a study of mussel populations from a single Nova Scotian embayment. Can. J. Fish. aquat. Sci. 40,443-451.

Gosling, E. M., 1984. The systematic status of Mytilus galloprovincialis in Western Europe: a review. - Malacologia 25, 551-568.

Gosling, E. M. \& Wilkins, N. P., 1981. Ecological genetics of the mussels Mytilus edulis and $M$. galloprovincialis on Irish coasts. - Mar. Ecol. Prog. Ser. 4, 221-227.

Harris, H. \& Hopkinson, D. A., 1976. Handbook of enzyme electrophoresis in human genetics. North Holland Publ., Amsterdam.

Kautsky, N., 1982. Growth and size structure in a Baltic Mytilus edulis population. - Mar. Biol. 68, 117-133.

Koehn, R. K., 1978. Physiology and biochemistry of enzyme variation: the interface of ecology and population genetics. In: Ecological genetics: the interface. Ed. by P. F. Brussard. Springer, New York, 51-72.

Koehn, R. K., 1983. Biochemical genetics and adaption in molluscs. In: The Mollusca. Ed. by K. M. Wilbur. Acad. Press, New York, 2, 305-330.

Koehn, R. K. \& Gaffney, P. M., 1984. Genetic heterozygosity and growth rate in Mytilus edulis. Mar. Biol. 82, 1-7.

Koehn, R. K., Milkman, R. \& Mitton, J. B., 1976. Population genetics of marine pelecypods. IV. Selection, migration and genetic differentiation in the blue mussel Mytilus edulis. - Evolution 30 , $2-32$.

Koehn, R. K., Hall, J. G., Innes, D. J. \& Zera, A. J., 1984. Genetic differentiation of Mytilus edulis in eastern North America. - Mar. Biol. 79, 117-126.

Koehn, R. K. \& Immermann, F. W., 1981. Biochemical studies of aminopeptidase polymorphism in Mytilus edulis. I. Dependence of enzyme activity on season, tissue and genotype. - Biochem. Genet. 19, 1115-1142.

Koehn, R. K. \& Siebenaller, J. F, 1981. Biochemical studies of aminopeptidase polymorphism in Mytilus edulis. II. Dependence of reaction rate on physical factors and enzyme concentration. Biochem. Genet. 19, 1143-1162.

Levinton, J. S. \& Suchanek, T. H., 1978. Geographic variation, niche breadth and genetic differentiation at different geographic scales in the mussels Mytilus californianus and $M$. edulis. - Mar. Biol. $49,363-375$.

Moore, M. N., Koehn, R. K. \& Bayne, B. L., 1980. Leucine aminopeptidase (aminopeptidase-I), Nacetyl- $\beta$-hexoseaminidase and lysosomes in the mussel Mytilus edulis L., in response to salinity changes. - J. exp. Zool. 214, 239-249.

Murdock, E. A., Ferguson, A. \& Seed, R., 1975. Geographical variation in leucine aminopeptidase in Mytilus edulis L. from the Irish coasts. - J. exp. mar. Biol. Ecol. 19, 33-41.

Nei, M., 1972. Genetic distance between populations. - Am. Nat. 106, 283-292.

Remane, A. \& Schlieper, C., 1971. The biology of brackish water. Schweizerbart, Stuttgart, $372 \mathrm{pp}$.

Scholl, A., Corzilius, B. \& Villwock, W., 1978. Beitrag zur Verwandtschaftsanalyse altweltlicher Zahnkarpfen der Tribus Aphaniini (Pisces, Cyprinodontidae) mit Hilfe elektrophoretischer Untersuchungsmethoden. - Z. zool. Syst. Evolutionsforsch. 16, 116-132.

Scopes, R. K., 1968. Methods for starch gel electrophoresis of sarcoplasmic proteins. An investigation of the relative mobilities of the glycolytic enzymes from the muscles of a variety of species. Biochem. J. 107, 139-150.

Segerstråle, S., 1957. Baltic Sea. In: Treatise on marine ecology and paleoecologY. Ed. by J. W. Hedgpeth. Geol. Soc. Am., New York, 1, 751-800. (Mem. geol. Soc. Am. 67.)

Shaw, C. R. \& Prasad, R., 1970. Starch gel electrophoresis of enzymes - a compilation of recipes. Biochem. Genet. 4, 297-320.

Skibinski, D. O. F., Ahmad, M. \& Beardmore, J. A., 1978. Genetic evidence for naturally occurring hybrids between Mytilus edulis and Mytilus galloprovincialis. - Evolution 32, 354-364. 
Skibinski, D. O. F. \& Beardmore, J. A., 1979. A genetic study of intergradation between Mytilus edulis and Mytilus galloprovincialis. - Experientia 35, 1442-1444.

Skibinski, D. O. F., Cross, T. F. \& Ahmad, M., 1980. Electrophoretic investigation of systematic relationships in the marine mussels Modiolus modiolus, Mytilus edulis and Mytilus galloprovincialis (Mytilidae; Mollusca). - Biol. J. Linn. Soc. 13, 65-74.

Skibinski, D. O. F., 1983. Natural selection in hybrid mussel populations. In: Protein polymorphism: Adaptive and taxonomic significance. Ed. by G. S. Oxford \& D. Rollinson. Acad. Pr., London, 283-298.

Skibinski, D. O. F., Beardmore, J. A. \& Cross, T. F., 1983. Aspects of the population genetics of Mytilus (Mytilidae; Mollusca) in the British Isles. - Biol. J. Linn. Soc. 19, 137-183.

Snyder, T. P. \& Gooch, J. L., 1973. Genetic differentiation in Littorina saxatilis (Gastropoda). - Mar. Biol. 22, 177-182.

Spencer, N., Hopkinson, D. A. \& Harris, H., 1964. Phosphoglucomutase polymorphism in man. Nature, Lond. 204, 742-745.

Tedengren, M. \& Kautsky, N., 1986. Comparative studies of the physiology and its probable effect on size in blue musseis (Mytilus edulis L.) from the North Sea and the northern Baltic Proper. Ophelia 25, 147-155.

Templeton, A. R., 1981. Mechanism of speciation - a population genetic approach. - A. Rev. Ecol. Syst. $12,23-48$.

Theisen, B. F., 1978. Allozyme clines and evidence of strong selection in three loci in Mytilus edulis L. (Bivalvia) from Danish waters. - Ophelia 17, 135-142.

Voipio, A. (Ed.), 1981. The Baltic Sea. Elsevier, Amsterdam, 418 pp.

Ward, R. D. \& Beardmore, J. A., 1977. Protein variation in the plaice, Pleuronectes platessa L. Genet. Res. 30, 45-62.

Widdows, J., 1978. Physiological indices of stress in Mytilus edulis. - J. mar. biol. Ass. U.K. 58, 125-142.

Winterhalter, B., Feodén, T., Ignatius, H., Axberg, S. \& Niemiströ, L., 1981. Geology of the Baltic Sea. In: The Baltic Sea. Ed. by A. Voipio. Elsevier, Amsterdam, 1-121. 